\title{
$<$ Chapter 5> Environmental policies in East Asia: Origins, development, and future
}

\author{
AUTHOR(S):
}

Mori, Akihisa

\section{CITATION:}

Mori, Akihisa. <Chapter 5> Environmental policies in East Asia: Origins, development, and future. Basic Studies in Environmental Knowledge, Technology, Evaluation, and Strategy: Introduction to East Asia Environmental Studies 2016: 69-78

\section{ISSUE DATE:}

2016

URL:

http://hdl.handle.net/2433/255380

\section{RIGHT:}

This is an author's accepted manuscript (AAM) of a chapter published in 'Basic Studies in Environmental Knowledge, Technology, Evaluation, and Strategy: Introduction to East Asia Environmental Studies'. The final authenticated version is available online at: https://doi.org/10.1007/978-4-431-55819-4_5; The full-text file will be made open to the public on 23 February 2018 in accordance with publisher's 'Terms and Conditions for Self-Archiving'.; この論文は出版社版であり ません。引用の際には出版社版をご確認ご利用ください。;This is not the published version. Please cite only the published version. 


\title{
Chapter 5 Environmental policies in East Asia: Origins, Development and Future
}

\author{
Akihisa Mori
}

\section{Abstract}

Environmental policies vary, depending on how one frames and defines environmental challenges. Underlying causes of the environmental challenges in East Asia can be classified as market failure, undefined ownership, government and/or institution failure, and globalization, and their combination. The government of each country have seen the underlying causes as they wanted, and chose policy instruments based upon their recognition, Coupled with the differences in economic development, pressures to the environmental challenges and their management capacity, this has brought about difference in the choice of policy instruments, enforcement, effectiveness and distributional impacts.

For an environmental policy to be more effective, it is indispensable for the government to frame environmental challenges and to define their underlying causes properly. Then all the government ministries and the political leaders should share the proper framing and definition so that they will take the environment into account in implementing their sectoral policies; in other words, implement preventive measures and convince people and firm to integrate the environment into their activities.

Keywords: framing, underlying causes, economic growth, East Asia

\section{Framing environmental challenges and environmental policies}

Environmental policies are put in place by governments to deal with environmental deterioration that is officially recognized as being a problem. Therefore, policies differ, depending on how the government frames and defines environmental deterioration.

The government does not always define the problem that enables it to address the root causes. Sometimes the problem is defined to make the results appealing to the citizens, or to expand the interest of the political leaders and their supporters.

In case deforestation is viewed as excessive logging without consideration for the recovery of the forest, logging ban or allow it within an ecological limit become appropriate policy response. However, such a policy may pose a political risk if the logging company exerts political influence. The political party can avoid such a risk if the government defines the underlying cause as shifting cultivation (slash-and-burn farming) by farmers living in the forest: as long as farmers who are operating shifting cultivation have feeble political and economic influence and thus have difficulty in delivering their voices, the government regard banning shifting cultivation and providing an alternative livelihood (which is unfavorable for farmers) as the "appropriate" policy measure. The weaker the farmers are, the more likely the government defines the underlying cause like this.

On the other hand, in case the government defines the underlying cause as a lack of government capacity, it becomes convincing for the Forest Department to implement measures that expand their profit, say, to increase their staff and budget. 
Referring to the above mentioned relationship between framing and 'appropriate' solution, this chapter takes a stock of root causes of environmental challenges to show how East Asian countries have defined them and implemented environmental policies. Then we prospect development of their environmental policies.

\section{Framing environmental problems in neoclassical economics}

Neoclassical economics has framed environmental problems as market failure due to environmental externality or lack of market. People tend to undervalue the environment, thus put inappropriate price in the market. This leads to excess consumption of environmental goods and services, forcing society to bear the cost of environmental deterioration or bring about resource depletion.

Unclear definition of property right provides additional incentive for the excess consumption. So long as the ownership of environmental resources is properly defined, the owner is expected to engage in sustainable use in order to maximize their value and to dissuade illegal development/use of environmental resources.

In reality, however, the government does not define legally binding property right to all the environmental resources. It does not admit legal registration and define ownership of some lands, especially ones located in frontier areas where the central government is hard to control, while land is one of the most basic components of human economic activity. In Japan, while Toyotomi Hideyoshi, the governor in the late 1500s, made a comprehensive survey to define land ownership and productivity as a way to identify the taxpayer and amount of tax levied (Taiko kenchi). The survey was limited to paddy rice field and did not cover mountains and forests. In the $17^{\text {th }}$ century, the successor defines most of the mountains yielding abundant timber as the ownership of the Tokugawa shogunate. However, communities nearby were allowed to manage the areas as common-pool resources and to harvest non-timber forest products such as firewood, charcoal, or bamboo shoots to supplement their income. It was not until the Civil Code was established in the Meiji era that the representative of the community became the owner of the land on the consensus that the land was commonly owned (owned by the community). While the radical land reform after the World War II kept the land ownership in the forest areas intact, inheritance tax charged to the registered representative de facto accelerated the shift from communal toward private ownership. Coupled with, significant decline in earning from forest and increasing income opportunity at urban and industrial areas, heavy inheritance tax has prompted children of the owners to give up land ownership and immigrate to urban areas. Insufficient inspection and updating of local government has increased the unclearly defined land ownership in those areas.

Furthermore, there remains uncertainty in predicting environmental impacts that current economic activity may cause. Human do not completely know the natural laws governing the ecological system. This disables them to have a futures market to make an inter-temporal trade of environmental resources. Cost of environmental resources depletion and deteriorating environment in the future is not fully reflected in the price in the current market. 
Globalization can expand the above-mentioned environmental externality. Freer international trade and foreign direct investments may not only expand resources depletion and industrial development that will cause environmental pollution but also increase consumption that brings about greater waste emission. In the long term, a country may specialize into industries with high resource- and/or environmental intensity in order to make the best use of comparative advantage in foreign trade. This will simply aggravate resource depletion and environmental pollution.

When we frame environmental challenges like this, the solution will be to legally define property right to environmental resources. This will constitute the basis for appropriate valuation of the environment. Market will bring about an efficient solution if the environmental value is appropriately priced as a tax or in the emissions trading.

On the other hand, environmental problems can be framed as policy and institutional failure. A government implements policies for economic development in order to attain multiple purposes of poverty alleviation, enhancing legitimacy of the ruling party, and increase in revenue for their discretion. It also implements policies to protect and expand the vested interest of their political supporters such as the military, political elites, industry, and massive population. While it implements policies and initiates development projects that benign for society and environment, reducing regional and/or urban-rural income gap. it pushes the ones that may cause negative environmental impacts. In addition it often disregard opinions of the affected people. The government even takes over land entitlement that local communities have traditionally and collectively owned for sustainable use to give concession on logging and/or reforestation for private companies and to protect watershed, It sometimes does this without agreement of the communities, excusing that such entitlement is not legally defined,

An environmental challenge can be also recognized as the 'implementation deficit:' that is, even if the department in charge of environment in the central government implements more stringent environmental laws and regulation, other ministries and local governments do not enforce them strictly and companies do not comply with them. This holds especially true in cases of weak penalty for violation, of difficulty in proving cause and effect, or of high transaction costs incurred to reach an agreement.

These descriptions imply that environmental problems will not be solved by government initiative if the main underlying cause is the policy or institutional failure. Even if international society convinces the government to implement environmental policies that is comparable to them, there is no guarantee that the government is willing to and is capable of implementing them strictly. It is worth scrutinizing political economy of environmental policies, especially domestic factors that work to develop them.

\section{Economic and systematic cause of environmental problems in East Asia}

East Asian countries have suffered from a variety of environmental challenges, which can be framed as the one of market failure, unclearly defined ownership, government and/or institutional failure, and globalization. 
First of all, they have taken development strategy and promoted compressed industrialization that enabled them to rapidly catch up with the industrialization process that developed countries had gone through over 100 years. They have placed higher priority on economic growth than environmental conservation. They have not developed environmental policies and institutions in commensurate with the industrialization. They were not willing to take policy instruments that shift the environmental costs from society to producers that caused environmental pollution and destruction, at the earlier stage of economic development. That is to say, the government left the market failure untouched. This holds true not only in capitalist countries but also in socialist countries where the government adjusted production and consumption and thus was expected to control environmental pollution under a planned economy. In reality, socialist countries did not operate a planned economy in such a way that could control pollution. For example, China dispersed industrial plants to a variety of region, not for the sake of minimizing pollution, but adverse impacts of possible future invasion of the United States. However, this location dispersion disabled China to take advantage of economies of scale, lowering resource efficiency, and worsening environmental pollution.

Allocation of property right was also an underlying cause of environmental degradation. Land is defined as state ownership not only in socialist countries such as China and Viet Nam but also in capitalist countries such as the Philippines and Thailand. Only land use title is allowed to private companies and residents. The government provided logging concession to private companies as a means of acquiring foreign exchange, disregarding traditional entitlement of the communities. However, private companies often conducted illegal logging beyond the boundaries as the government had limited capacity to monitor their activities. They overexploited the environmental resources while did not fulfill their duty of forest restoration. Farmers also encroached the degraded forest for agricultural extension. Such activities caused frequent flooding and increased tensions with downstream farmers and urban dwellers. This came to the forest policy change from production to conservation. Nonetheless, this policy change has shown limited impacts on conservation. In the Philippines, on the one hand, the government allowed communities to grow up economic trees under the reforestation program, reconciling community livelihood with forest conservation. Chinese government launched a sloping land conservation program in 1998 that forced farmers in the government designated reforestation areas to plant ecological as well as economic trees, in exchange of five to seven years of compensation for their income loss. In Thailand, on the other hand, the government has promoted industrial plantation of non-native but fast-grown and economical tree species such as eucalyptus and acacia in the name of reforestation program, and it raised a concern that this had negative impacts on the ecological system.

In order to tame the frustration of poor people, the government has supplied utility services at a subsidized price. It has not frequently adjusted the price in accordance with inflation to stabilize consumer price. This resulted in excess consumption of environmental resources at the expense of government budget. Such government price subsidization is greater in resource producing countries. For example, the share of fuel subsidy in government expenditure raise up to $18.8 \%$ in 2005 and it rose as high as $22.6 \%$ in 2008, increasing budget deficit in Indonesia. The Indonesian government 
decided to cut the subsidy in 2005 and 2008. It suspended subsidy cut in 2012 in the face of citizens' protests, but it implemented in 2013 when it was predicted that the United States would abolish its purchase program of Indonesian national bonds. However, it turns out to be a temporally decline in demand as rising incomes increases demand for cars and accordingly transport fuel. China, by contrast, turned from a net energy exporter to an importer in the late 1990s, and gradually cut fuel subsidy and liberalized coal market to allow price increase in the late 2000s.

Impact of globalization was greater among developing countries that attracted massive foreign direct investment for export-oriented growth while did not develop capacity for the environment. In Thailand, capital-intensive petrochemical industries became densely located, causing serious environmental pollution in Eastern Seaboard of Map Ta Phut. Globally increasing demand, coupled with local governments' provision of concession without strict enforcement has drawn massive investment on develop palm oil plantation, accelerating deforestation and causing haze in ASEAN region.

\section{Experience of environmental policies in East Asia}

At the early stage of economic development, governments in many East Asia countries regarded that victims should allow environmental damages for the sake of nation or society in general. They unheeded complaints and petitions that victims made against industrial pollution and development projects. They tried to tame the victims by paying small amount of compensation or financial assistance without investigating the cause and effect or altering the production technologies or designs of development projects. These measures did not stop environmental deterioration, and made the damage worse. Victims stepped up protest against polluters and developers, resorting to force such as blocking the transport of goods to industrial plants or the project sites. In countries that established a democratic institution such as Japan, Korea, Taiwan and Thailand, victims organized themselves to build and develop a large-scale environmental movement. They brought environmental cases to the court and supported candidates who were proclaiming environmental improvement to be elected in governors, mayors and parliament to place pressures for policy change.

It was not until these radical conflicts, lawsuits, and elections forced companies and governments to pay compensation and to suspend plants operation or construction that the government recognized industrial pollution as being a bottleneck on economic development. Then they enacted environmental laws and regulations, organized environmental administrative and fiscal system at central and local governments. They also prescribed public hearings and participation in environmental impact assessment laws and constitutions, attempting to make environmental impact assessment a practical means of consensus building among stakeholders.

In Japan, the government defined prevention of human health damages as environmental policy goal after several years of serious health damages from industrial pollution that was spread over Japan. Amid the enthusiasm that supported priority in environmental protection over economic growth, the government came to see stringent industrial pollution policies as indispensable means for sustainable economic growth, and proclaimed the policy goal that reduced environmental pollution to the level 
of not causing health damage. The government initiated epidemiological surveys to set environmental standard below which health damage is not caused. It also accelerated research and development of pollution abatement technologies that ensured to achieve the environmental standards, demonstrating to urge companies to invest on them.

These countries did not frame industrial pollution as market failure. The government initiated to develop environmental infrastructure including sewage systems, waste treatment/disposal facilities to accept both industrial and domestic wastewater/waste to clean up the dirty environment within a short period. It went further to provide subsidized loans with companies that invested on pollution abatement technologies even if these policy measures were against the polluter-pays principle.

Some governments even regard pollution haven and/or resource depletion in neighboring lowincome countries as a "solution," instead of tackling domestic environmental challenges seriously. Thai government has faced fierce protests against new coal-fired power plants since Mae Moh lignitefired power plant discharged massive sulphur dioxides that led to hospital admission of more than thousand nearby residents. After this incident, the 1992 Environment Act and the 1997 Constitution clearly stipulated environmental impact assessment (EIA) in prior to the government approval of development projects. Nonetheless, the government approved the Hua Hin coal-fired power plant project in prior to EIA. This made people lose credibility to the government. The government did not implement industrial pollution prevention policies that were stringent enough to eliminate serious health damage at Map Ta Phut Industrial Estate in spite of almost twenty years of frequent and fierce protests. With the support of environmental victims in other region, the local residents filed a lawsuit in the administrative court at last. In 2009, the Supreme Administrative Court ruled that 65 out of 76 new industrial plant projects in the Map Ta Phut had to be suspended for the reasons of serious health damage among local residents and flaws in the procedure concerning negligent legislation stipulated in the Article 67, Section 2 of the 2007 Constitution. While 14 projects got approval by March 2010, and 25 projects could go ahead, this court ruling made it difficult to construct petrochemical industrial complex. Nonetheless, worsening political turmoil and social division after the 2006 coup disabled the Thai government to implement more stringent environmental regulations or to make more strict enforcement. This has prompted Thai government to resort to financial assistance for, or participating in hydroelectric power generation projects in Laos and Myanmar as well as natural gas development and industrial estate development projects in Myanmar as a way of mitigating bottleneck on economic growth.

China is also recognizing environmental pollution as a bottleneck on economic growth. It is going through serious environmental pollution, causing health and ecological damages and land exploitation around the nation, raising a number of protests against factories, development projects and waste incineration plants. Chinese government frames the underlying causes as obsolete state enterprises and local protectionism; that is, the local government does not strictly enforce environmental laws and regulations on local companies to protect them and thus local government vested interests. Based on this framing, it implemented stringent environmental regulations increased environmental investment, coupled with the transition to the market economy to make large and key state enterprises 
survive while shut down low-competitive ones. This framing, however, has led the government to see vehicle as the underlying cause of PM 2.5 instead of industrial plants and quality of transport fuel, allowing the China National Petroleum Corporation, one of the major state enterprises in China to resist to the government requirements on upgrading investments, This has made it difficult to enhance effectiveness of countermeasures against air pollution.

In order to break the local protectionism, the State Environmental Protection Administration (SEPA) initiated shut down polluting plants in the designated heavy pollution areas such as the Huai River basin, allowed watchdog functions to citizens and media and disclosed environmental rating of the firms as a way of complementing government limited environmental capacity, but to the extent they did not cause fierce opposition movement against the government. It has also implemented the total emission control on sulphur dioxide and COD in the environmental five-year plan since 1995, and allocated a reduction target to each local government to comply with them. To ensure their compliance, it implemented a “one vote rejection system” that includes achievement of energy saving and/or total pollutant emission targets as one of the key performance evaluation criteria of local government leaders. Finally it has provided supporting measures, financial incentives and reputation to local governments that initiated eco-industrial park and low carbon urban development projects in the same line with the SEPA.

Nonetheless, local governments have sought for local economic growth at the cost of environment and society. This is in part due to the fact that the central communist party still places priority on economic performance in evaluating local government leaders. This has pushed local governments to compulsory acquisition of land to develop industrial plants and real estate with a meager amount of compensation, excusing that land is under state ownership. While the central government mandates an environmental assessment in prior to the development, developers do it as an add-on without significant revision in view of the environment, and only after the approval of the project. This has in part increased environmental pollution and the number of landless farmers.

By contrast, Malaysian government has not recognized environmental deterioration as a bottleneck on economic growth. It has framed conversion of rainforest for palm oil plantation as an inevitable price to be rich. It did not regard it necessary to implement stringent regulations and strict enforcement of Malaysian plantation companies since haze pollution suffered by Malaysia and Singapore mainly originates on Sumatra and Kalimantan Island in Indonesia and the existence of a variety of polluters, ranging from local smallholders, transmigrated people toward large scale Indonesian as well as Malaysian companies has blurred the responsibility.

In the meanwhile, international NGO and European countries showed their concern, requesting sustainable palm oil production that takes environmental impacts into consideration. In response, the WWF and Malaysian Palm Oil Association (MPOA) established the Roundtable on Sustainable Palm Oil (RSPO), setting 8 principles and 43 standards for sustainable production and granted an RSPO certified label for palm oil that satisfies these standards. However, MPOA has interfered with implementation of measures to promote sustainable production, claiming that the additional cost to obtain RSPO certificate cannot be recovered by export sales with the premium price. The MPOA goes 
further to wonder if it should withdraw from RSPO. In the meantime, the Malaysian government and research institutions are advancing research and commercialization of zero-emission palm oil farms and factories to reduce environmental impact of palm oil production in a way that companies can still obtain profit.

\section{Summary and Prospects}

The above experiences of environmental policies in East Asia demonstrate how East Asian country governments have reconciled environmental policies with economic growth. An Environmental policy can poses political risks to governmental party as it has effects on economic activities and income distribution, including their vested interests. The government does not recognize environmental challenges as problems to be solved and has no incentive to bring in policies that may risk its legitimacy and political and economic support unless it faces fierce protests and pressures against environmental challenges. It was not until the government recognizes that environmental policies will enhance its legitimacy and political support that is, benefits of implementing environmental policies exceeds cost of leaving them untouched, that it begins to implement environmental policies. However, it tends to frame the challenges that can protect or even increase its political and economic benefits and to implement policy instruments. This leads to the choice of policy instruments that do not properly address the underlying causes and/or have negative implications to macroeconomic stability in expanding government expenditure too much or socially vulnerable people. As long as the government avoids proper framing of underlying causes, implemented environmental policies do not effectively address the negative impacts of economic growth on environment or society, which may become a bottleneck on economic growth, leading to division in the society and loss of legitimacy of the party in power.

In order to avoid such a situation, it is indispensable for the government to frame environmental challenges and to define their underlying causes properly. Then all the government ministries and the political leaders should share the proper framing and definition so that they will take the environment into account in implementing their sectoral policies; in other words, implement preventive measures and convince people and firm to integrate the environment into their activities. Environmental policies should be evolved to go beyond the regulation of individual plant and project; specifically, policies that advance green supply chain management; long-term strategies and plans with ambitious emission reduction target, in consideration for environmental impacts by different types of emission sources; and to allocation of national budget and grant in consideration for their environmental impacts (Mori, 2013).

Implementing these preventive and integrative policies would claim economic and political cost in a short-term. However, commitment to a long-term ambitious targets and gradual implementation with flexible measures enables the government to avoid international and domestic pressures for rapid implementation while convince people and firm to place it into their core activities. This holds especially true if all the political parties agree on the long-term ambitious targets or policy making process is changed to institutionalize consideration of the policy impacts on the environment. Such 
kind of environmental policies are expected to reduce political, economic and social costs to the government, making it to brave enough to frame environmental challenges properly, to define and address the underlying causes properly and to plan to implement environmental policies for the benefit of all in East Asia,

\section{References}

Hideki Kitagawa (author and editor) "Current situation and issues of executing policies of environmental law in China” Koyo Shobo, 2011

Akihisa Mori (ed.), Democratization, Decentralization and Environmental Governance in Asia, Kyoto: Kyoto University Press, 2012.

Akihisa Mori (author and editor) "Environmental policies in East Asia” Showado Co. Ltd., 2012

Akihisa Mori (author and editor) "Integrating environmental policies - Reform in policy making in Japan and Europe, and its implementation in transportation” Minerva Shobo Co. Ltd., 2013

Akihisa Mori, Petch Pengchai, So Sasaki, “Thailand: Retarded environmental policies in political chaos”, Japan Environmental Council "Environmental White Paper in Asia” Editing committee (edit.) “Environmental White Paper in Asia 2011/12” Toyo Keizai Inc. 2010, pp.241-249. 